\title{
KAJIAN ALIRAN INLET SUDETAN SUNGAI CILIWUNG KE KANAL BANJIR TIMUR UNTUK PENGENDALIAN BANJIR JAKARTA
}

\author{
Rica Yunita ${ }^{1}$, Moh. Sholichin ${ }^{2}$, Tri Budi Prayogo ${ }^{2}$ \\ ${ }^{1}$ Staf Balai Besar Wilayah Sungai Ciliwung-Cisadane, Fakultas Teknik, Universitas Brawijaya, Malang \\ ${ }^{2}$ Dosen Jurusan Teknik Pengairan, Fakultas Teknik, Universitas Brawijaya, Malang \\ e-mail : ric4yunita@gmail.com
}

\begin{abstract}
ABSTRAK: Sudetan Sungai Ciiwung ke Kanal Banjir Timur (KBT) merupakan salah satu cara untuk mengurangi banjir pada Sungai Ciliwung. Bangunan ini diharapkan mampu mengalihkan debit banjir sungai Sungai Ciliwung ke KBT sebesar $60 \mathrm{~m}^{3} /$ detik. Penelitian ini bertujuan untuk mengevaluasi hasil model fisik dengan melakukan perbandingan aliran pada model fisik terhadap perhitungan secara teoritis dan analisa satu dimensi menggunakan HEC-RAS. Perhitungan teoritis dilakukan dengan metode De Marchi, side weir, percabangan anak sungai dan aliran melalui pulau. Perhitungan melalui 4 metode dan hasil simulasi HEC-RAS didapatkan beberapa perbedaan terhadap debit, kecepatan dan tinggi muka air pada inlet floodway (sudetan) Sungai Ciliwung ke KBT namun tidak terlalu signifikan. Baik hasil uji model fisik maupun perhitungan teoritis dan simulasi HEC-RAS debit $60 \mathrm{~m}^{3} /$ detik dapat terjadi apabila elevasi muka air di Sungai Ciliwung diatas $+12,342 \mathrm{~m}$.
\end{abstract}

Kata kunci: kapasitas debit, inlet sudetan, banjir, HEC-RAS

\begin{abstract}
Ciliwung-East Flood Canal Shortcut is an effort to reduce the flood risk and impact to the Ciliwung River. This project is expected would be able to divert flood discharge from the Ciliwung River to the East Flood Canal by $60 \mathrm{~m}^{3} / \mathrm{sec}$. This Research has a purpose of evaluating the result of a physical model by doing some flow comparison to the calculation theoretically and one dimension analysis. The theoretical calculation was done by using De Marchi method, side weir, river confluence and flow through an island while the one dimension analysis using HEC-RAS. Calculation by four method and HEC-RAS simulation obtained some differences to discharge, flow rate and water level at the floodway inlet but not too significant. Based on the result of physical model test nor theoretical calculation and HEC-RAS simulation the $60 \mathrm{~m}^{3} / \mathrm{sec}$ discharge is able to reach within the condition of the Ciliwung River water level above $+12,342 \mathrm{~m}$.
\end{abstract}

Keywords : discharge capacity, inlet floodway, flood, HEC-RAS

Provinsi DKI Jakarta memiliki permasalahan kebencanaan yang komplek. Dengan luas $661,52 \mathrm{~km}^{2}, \quad 40 \%$ atau 24.000 hektar merupakan dataran rendah dengan ketinggian rata-rata di bawah permukaan air laut. DKI Jakarta juga merupakan pertemuan sungai dari bagian Selatan dengan kemiring an dan curah hujan tinggi. Terdapat 13 sungai yang melewati dan bermuara ke Teluk Jakarta (BPBD DKI Jakarta, 2013). Secara alamiah, kondisi ini memposisikan wilayah DKI Jakarta memiliki kerawanan yang tinggi terhadap banjir ditambah lagi dengan adanya faktor eksternal akibat ulah manusia.

Titik banjir yang sering menjadi masalah di Jakarta adalah Sungai Ciliwung terutama ruas Cawang - Pintu Air Manggarai. Untuk mengatasi banjir di Sungai Ciliwung berbagai cara ditempuh, salah satunya adalah dengan mengoptimalkan kapasitas Kanal Banjir Timur 
(KBT) sehingga kemudian direncanakan pembangunan Sudetan Sungai Ciliwung ke Kanal Banjir Timur melalui Sungai Cipinang. Pembangunan ini dimaksudkan untuk mengalihkan sebagian debit banjir Sungai Ciliwung ke KBT sebesar $60 \mathrm{~m}^{3} /$ detik.

Pada tahun 2008 telah dilakukan perencanaan dan pemodelan fisik terkait pembangunan Sudetan ini oleh Balai Besar Wilayah Sungai Ciliwung-Cisadane, namun pada tahun 2014 terjadi review desain normalisasi Sungai Ciliwung dimana elevasi Sungai Ciliwung diturunkan lagi sekitar \pm 83 $\mathrm{cm}$ dari elevasi awal rencana normalisasi yang mengakibatkan sistem sudetan mengalami perubahan. Kemudian dilakukan kembali pemodelan fisik hidrolika pada tahun 2015 .

Pemodelan fisik ini diperlukan untuk membuktikan apakah debit pengalihan yang ditentukan dalam kriteria desain yaitu 60 $\mathrm{m}^{3} /$ detik dapat tercapai. Berdasarkan permasalahan di atas dan dikarenakan belum selesai terbangunnya prototip, untuk menguji keakuratan dan memvalidasi hasil model fisik maka akan dilakukan perbandingan hasil uji model fisik dengan hitungan teoritis dengan metode De Marchi, side weir, percabangan anak sungai dan aliran melalui pulau serta analisa satu dimensi dengan simulasi menggunakan HEC-RAS.

Tujuan dari studi ini adalah untuk mendapatkan perbandingan aliran yang terjadi di inlet sudetan Sungai Ciliwung ke Kanal Banjir Timur antara hasil uji model fisik dengan hasil perhitungan analitis dan simulasi HECRAS pada saat debit banjir Sungai Ciliwung 2 tahun, 5 tahun, 10 tahun, 25 tahun, 50 tahun dan 100 tahun. Juga untuk mengetahui bagaimana kesesuaian antara hasil uji model fisik dengan perhitungan analitis dan hasil simulasi HECRAS.

\section{METODOLOGI}

\section{Lokasi Studi}

Lokasi Penelitian ini berada di Wilayah administrasi Jakarta Timur, Kecamatan Jatinegara meliputi Kelurahan Bidara Cina, Cipinang Cempedak, Cipinang Besar Selatan dan Cawang. Secara geografis berada dikisaran $106^{\circ} 49^{\prime} 35^{\prime \prime}$ Bujur Timur dan 06 $10^{\prime} 37^{\prime \prime}$ Lintang Selatan.

Lokasi trase sudetan berada di wilayah Jakarta Timur. Daerah ini relatif berpenduduk padat pemukiman dan kawasan perumahan dengan jalur lalu lintas yang cukup padat. Selain berada pada posisi jalur padat pemukiman, dan merupakan central bisnis.

\section{Pengumpulan Data}

Data yang digunakan adalah data sekunder, antara lain:

1. Potongan melintang dan memanjang Sungai Ciliwung yang telah dinormalisasi dan inlet sudetan Sungai Ciliwung ke KBT.

2. Debit banjir rancangan Sungai Ciliwung kala ulang 2, 5, 10, 25, 50 dan 100 tahun berdasarkan Review Desain Normalisasi Kali Ciliwung tahun 2014.

3. Data hasil model tes hidrolika Sudetan Sungai Ciliwung Ke Kanal Banjir Timur.

4. Data pendukung lain yang relevan.

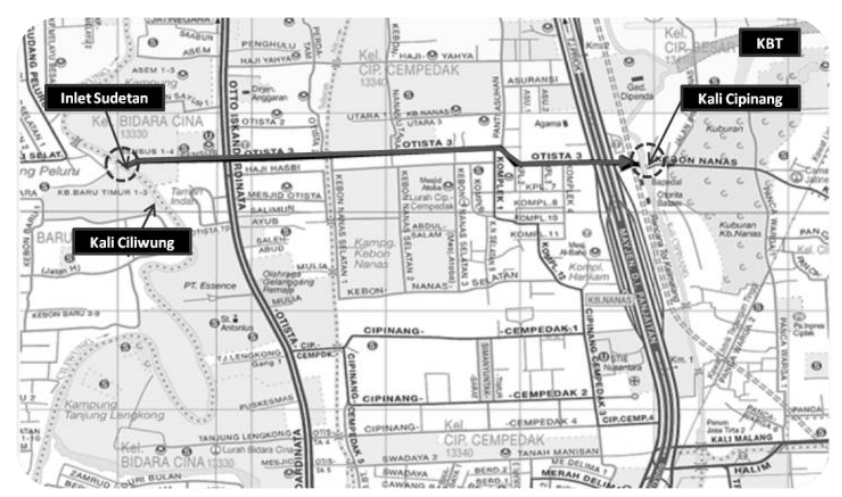

Gambar 1. Peta Lokasi Studi Sumber : BBWS Ciliwung-Cisadane (2015)

\section{Pengolahan Data}

Adapun langkah-langkah pengerjaan studi, sebagai berikut:

1. Menganalisa hasil uji model fisik pada inlet Sudetan Sungai Ciliwung ke KBT.

2. Menghitung dan menganalisa kapasitas debit pada inlet sudetan (floodway) dengan metode De Marchi, metode side weir, percabangan anak sungai dan aliran melalui pulau.

\section{Metode De Marchi}

De Marchi memberikan konsep mengenai pelimpah samping dengan menganggap energy disepanjang side weir adalah konstan $(\mathrm{So}=\mathrm{Sf})$ seperti terlihat pada gambar 2, sehingga debit $\mathrm{q}$ diatas pelimpah per satuan panjang dengan tinggi w adalah:

$$
d Q_{w}=\frac{2}{3} C_{d} \sqrt{2 g}(h-w)^{3 / 2} \Delta x
$$


$\mathrm{C}_{\mathrm{d}}=$ koefisien debit

$\mathrm{w}=$ tinggi puncak pelimpah $(\mathrm{m})$

$\mathrm{h}=$ tinggi air $(\mathrm{m})$

$\mathrm{g}=$ percepatan gravitasi $\left(\mathrm{m} / \mathrm{det}^{2}\right)$

Tabel 1. Persamaan Koefisien Debit $\left(\mathrm{C}_{\mathrm{d}}\right)$ untuk persamaan De Marchi

\begin{tabular}{l|c}
\hline Sumber & Persamaan Koefisien Debit $\left(\mathrm{C}_{\mathrm{d}}\right)$ \\
\hline Nandesamoorthy (1972) & $C_{d}=0,432\left(\frac{2-F_{r}{ }^{2}}{1+2{F_{r}}^{2}}\right)^{0,5}$ \\
\hline Subramanya dkk (1972) & $C_{d}=0.611\left(1-3{F_{r}}^{2}\right)^{0,5}$ \\
\hline Yu-Tech (1972) & $C_{d}=0,623-0,222 F_{r}$ \\
\hline Hager (1987) & $C_{d}=0,485\left(\frac{2+F_{r}^{2}}{2+3 F_{r}^{2}}\right)^{0,5}$ \\
\hline Singh dkk (1994) & $C_{d}=0,33-0,18 F_{r}+0,49\left(\frac{w}{h_{0}}\right)$ \\
\hline Jalili dkk (1996) & $C_{d}=0,71-0,41 F_{r}+0,22\left(\frac{w}{h_{0}}\right)$ \\
\hline Borghei dkk (1999) & $C_{d}=0,7-0,48 F_{r}-0,3\left(\frac{w}{h_{0}}\right)+0,06 \frac{L}{b}$ \\
\hline Emiroglu dkk (2014) & $C_{d}=\left[0,836+\left(-0,035+0,39\left(\frac{w}{h_{o}}\right)^{12,69}+0,158\left(\frac{L}{b}\right)^{0.59}\right.\right.$ \\
& $\left.\left.+0,049\left(\frac{L}{h_{o}}\right)^{0,42}+0,244 F_{r}^{2,125}\right)^{3,018}\right]^{5,36}$ \\
\hline
\end{tabular}

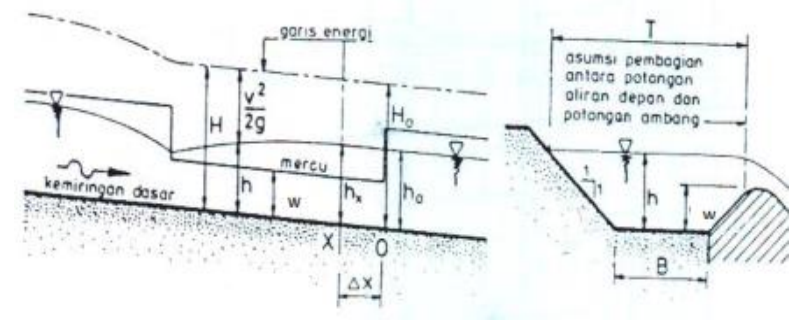

Gambar 2. Sketsa Saluran dengan Pelimpah Samping

Sumber: KP 04 (1986)

Untuk menentukan nilai koefisien debit $(\mathrm{Cd})$ telah banyak dilakukan penelitian dan percobaan pada studi-studi sebelumnya. Nandesamoorthy dkk, Subramanya dkk, Yutech, Ranga Raju dkk, Hager, Cheong, Singh dkk, Jalili dkk, and Borghei dkk, Swamee dkk, Ghodsian, Bagheri dkk, memberikan persamaan koefisien debit $\left(\mathrm{C}_{\mathrm{d}}\right)$ yang berbedabeda (tabel 1). Koefisien debit ini tergantung pada parameter dimen-sional $(\mathrm{Fr}, \mathrm{L} / \mathrm{b}, \mathrm{L} / \mathrm{ho}$, ho/w). Pada studi ini akan dilakukan perhitungan nilai $\mathrm{C}_{d}$ dengan menggunakan persamaan pada tabel 1 .

\section{Metode Side Weir}

Raju (1989) melakukan percobaan pelimpah samping dengan sudut $90^{\circ}$ terhadap saluran utama untuk aliran subkritis. Mencari nilai $\mathrm{Q}_{2}$ dan $\mathrm{Q}_{\mathrm{w}}$ yang tepat sehingga mendapatkan lebar pelimpah samping yang sesuai dengan hasil percobaan. Melalui rumus sebagai dibaw ah ini:

$$
\begin{aligned}
& E=h+\frac{Q^{2}}{2 g B^{2} h^{2}} \\
& \emptyset_{2}=\frac{2 E-3 W}{E-W} \sqrt{\frac{E-h}{h-W}}-3 \sin ^{-1} \sqrt{\frac{E-h}{h-W}} \\
& E_{1} / h_{c}=\frac{E_{1}}{\sqrt[3]{\left(\frac{Q_{1}}{B_{1}}\right)^{2} \frac{1}{g}}}
\end{aligned}
$$

Dengan mempertimbangkan pengaruh panjang puncak pelimpah Raju menguraiakan koefisien debit $\mathrm{C}_{\mathrm{d}}$.

$C_{d}=\left(0,81-0,60 F_{1}\right) K$

Dimana $\mathrm{K}$ merupakan parameter yang mempertimbangkan pengaruh pan-jang puncak dengan nilai $\mathrm{K}$ sebagai berikut: untuk $(\mathrm{h} 1-\mathrm{W}) / \mathrm{L} \geq 2,0$

$\mathrm{K}=1,0$

untuk $(\mathrm{h} 1-\mathrm{W}) / \mathrm{L} \geq 2,0$

$\mathrm{K}=0,80+0,10(\mathrm{~h} 1-\mathrm{W}) / \mathrm{L}$ 


\section{Metode Percabangan Anak Sungai}

Metode percabangan anak sungai menggunakan metode tahapan standar. Metode tahapan standar ini sangat baik bila digunakan pada saluran alam. Pada tahapan standar, bila tidak mengetahui ketinggian air maka dapat menggunakan ketinggian air pada jarak yang cukup jauh, diatas atau di bawah penampang awal (Chow, 1997).

$$
K=\frac{1,49 \times A \times R^{2 / 3}}{n}
$$

\section{Metode Aliran Melalui Pulau}

Aliran yang melalui pulau haruslah dalam keadaan sub kritis dengan menentukan ketinggian muka air di $\mathrm{Q}_{1}$ dan $\mathrm{Q}_{2}$, melalui lengkung debit maka dapat digambarkan perca-bangan antara tinggi muka air keduanya.

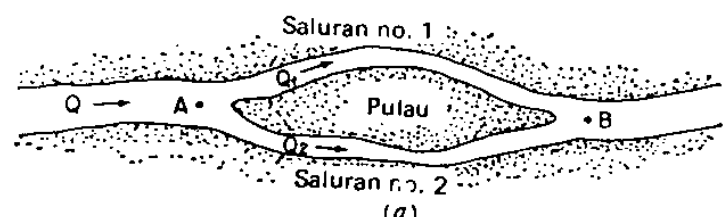

Gambar 3. Sketsa Aliran Melalui Suatu Pulau

Sumber: Chow, 1997

Perhitungan air melalui pulau dalam studi ini dikonsentrasikan pada $\mathrm{Q}_{\text {hulu }}$. Sehingga nilai $\mathrm{Q}_{\text {hulu }}=\mathrm{Q}_{1}+\mathrm{Q}_{2}$ dengan rumus debit sebagai berikut (Chow, 1997):

$Q=K \sqrt{S}$

dengan:

$\mathrm{Q}=\operatorname{debit}\left(\mathrm{m}^{3} / \mathrm{det}\right)$

$\mathrm{K}=$ faktor bilangan murni bentuk saluran

$\mathrm{S}=$ kemiringan dasar saluran

3. Melakukan simulasi dan analisa hidrolika pada inlet sudetan dengan menggunakan bantuan software HEC-RAS (Hydrologic Engineers Center's River Analysis Sistem). Dari simulasi ini akan diketahui debit yang masuk ke inlet, kecepatan yang terjadi serta elevasi muka air.

4. Melakukan uji kesesuaian antara model fisik dengan perhitungan analitis dan simulasi HEC-RAS dengan menggunakan uji statistik yaitu analisis regresi, Mean Absolut Error (MEA), coefficient Performance (Cp), dan Root Mean Square Error (RMSE).

\section{HASIL DAN PEMBAHASAN \\ Hasil Uji Model Fisik}

Pemodelan fisik Sudetan Sungai Ciliwung Ke Kanal Banjir Timur ini dilakukan oleh Balai Besar Wilayah Sungai CiliwungCisadane. Dari hasil uji model fisik dilakukan sebanyak 4 seri dari seri-0 sampai seri-3. Seri3 merupakan penyempurnaan dari seri-0 sampai seri-2 dengan hasil sebagai berikut:

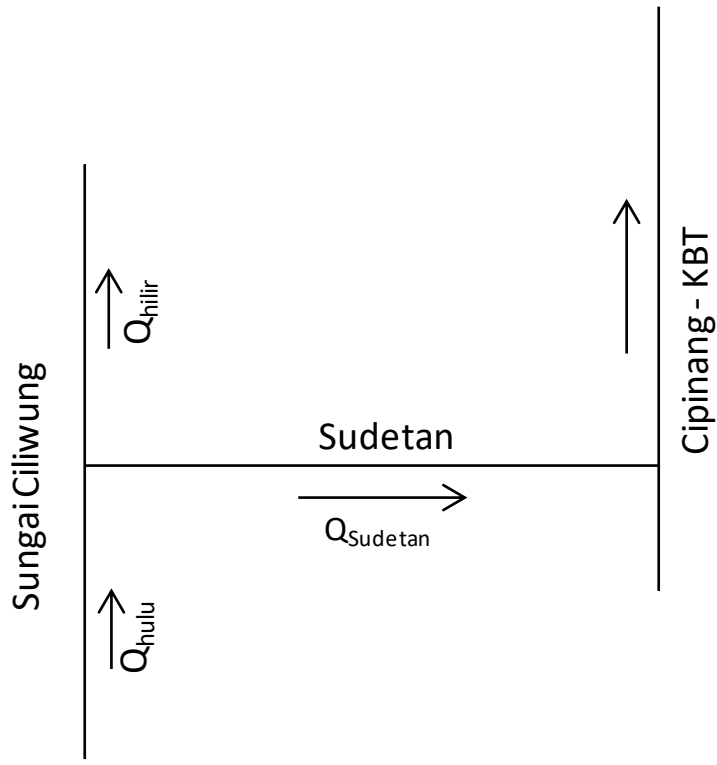

Gambar 4. Sketsa Sungai Ciliwung Ke KBT

Tabel 2. Hasil Uji Model Fisik Seri-3

\begin{tabular}{|c|c|c|c|}
\hline $\operatorname{Tr}$ & $\begin{array}{c}\text { Debit } \\
\text { Ciliwung } \\
\text { hulu }\end{array}$ & $\begin{array}{c}\text { Debit di } \\
\text { Inlet } \\
\text { Sudetan }\end{array}$ & $\begin{array}{c}\text { Elevasi } \\
\text { inlet } \\
\text { Sudetan }\end{array}$ \\
\hline Tahun & $\left(\mathrm{m}^{3} / \mathrm{det}\right)$ & $\left(\mathrm{m}^{3} / \mathrm{det}\right)$ & $(+\mathrm{m})$ \\
\hline 2 & 301 & 29 & 10,40 \\
\hline 5 & 400 & 51 & 11,49 \\
\hline 10 & 452 & 59 & 11,68 \\
\hline 25 & 509 & 74 & 12,17 \\
\hline 50 & 547 & 79 & 12,47 \\
\hline 100 & 572 & 81 & 12,70 \\
\hline
\end{tabular}

Sumber: BBWS Ciliwung-Cisadane, 2015.

\section{Analisa Kapasitas Debit Inlet secara Analitis}

\section{Metode De Marchi}

Salah satu metode untuk mengetahui debit aliran pada side weir secara analitis adalah dengan menggunakan persamaan De Marchi. De Marchi mengasumsikan bahwa energi spesifik yang terjadi di sepanjang pelimpah samping adalah konstan. Metode ini dapat dipakai apabila aliran yang terjadi adalah subkritis.

Persamaan De Marchi sensitif terhadap parameter koefisien debit. Dari perhitungan 
dengan menggunakan beberapa persamaan pada tabel 1 didapatkan koefisien debit $\left(\mathrm{C}_{\mathrm{d}}\right)$ yang bervariasi (tabel 3 ).

Dari tabel 4 diketahui perhitungan dengan menggunakan persamaan koefisien debit $(\mathrm{Cd})$
Emiroglu dkk memiliki nilai debit yang paling mendekati hasil model fisik. Didapatkan kesalahan relatif terhadap model fisik yaitu $0,728 \%$ sampai $6,171 \%$.

Tabel 3.Nilai Koefisien Debit $\left(\mathrm{C}_{\mathrm{d}}\right)$

\begin{tabular}{|l|c|c|c|c|c|c|}
\hline \multirow{2}{*}{\multicolumn{1}{|c|}{ Persamaan $\mathrm{C}_{\mathrm{d}}$}} & \multicolumn{7}{|c|}{ Nilai Koefisien Debit $\left(\mathrm{C}_{\mathrm{d}}\right)$} \\
\cline { 2 - 7 } & $\mathrm{Q}_{2}$ & $\mathrm{Q}_{5}$ & $\mathrm{Q}_{10}$ & $\mathrm{Q}_{25}$ & $\mathrm{Q}_{50}$ & $\mathrm{Q}_{100}$ \\
\hline Nandesamoorthy (1972) & 0,555 & 0,553 & 0,552 & 0,551 & 0,549 & 0,550 \\
\hline Subramanya dkk (1972) & 0,574 & 0,573 & 0,574 & 0,571 & 0,570 & 0,570 \\
\hline Yu-Tech (1972) & 0,559 & 0,557 & 0,557 & 0,556 & 0,556 & 0,555 \\
\hline Hager (1987) & 0,467 & 0,466 & 0,466 & 0,466 & 0,465 & 0,466 \\
\hline Singh dkk (1994) & 0,611 & 0,566 & 0,549 & 0,532 & 0,521 & 0,516 \\
\hline Jalili dkk (1996) & 0,446 & 0,463 & 0,469 & 0,474 & 0,477 & 0,483 \\
\hline Borghei dkk (1999) & 0,369 & 0,391 & 0,400 & 0,408 & 0,412 & 0,420 \\
\hline Emiroglu dkk (2014) & 0,412 & 0,411 & 0,397 & 0,397 & 0,396 & 0,396 \\
\hline
\end{tabular}

Tabel 4. Hasil Perhitungan Debit di Inlet Sudetan dengan Beberapa Persamaan $C_{d}$

\begin{tabular}{|l|c|c|c|c|c|c|}
\hline \multirow{2}{*}{\multicolumn{1}{c|}{ Persamaan $\mathrm{C}_{\mathrm{d}}$}} & $\mathrm{Q}_{2}$ & $\mathrm{Q}_{5}$ & $\mathrm{Q}_{10}$ & $\mathrm{Q}_{25}$ & $\mathrm{Q}_{50}$ & $\mathrm{Q}_{100}$ \\
\cline { 2 - 7 } & $\mathrm{m}^{3} / \mathrm{det}$ & $\mathrm{m}^{3} / \mathrm{det}$ & $\mathrm{m}^{3} / \mathrm{det}$ & $\mathrm{m}^{3} / \mathrm{det}$ & $\mathrm{m}^{3} / \mathrm{det}$ & $\mathrm{m}^{3} / \mathrm{det}$ \\
\hline Nandesamoorthy (1972) & 34 & 59 & 72 & 87 & 98 & 105 \\
\hline Subramanya dkk (1972) & 34 & 60 & 74 & 90 & 101 & 108 \\
\hline Yu-Tech (1972) & 34 & 59 & 73 & 88 & 99 & 106 \\
\hline Hager (1987) & 29 & 52 & 64 & 78 & 87 & 94 \\
\hline Singh dkk (1994) & 36 & 60 & 72 & 85 & 95 & 101 \\
\hline Jalili dkk (1996) & 28 & 52 & 64 & 78 & 90 & 96 \\
\hline Borghei dkk (1999) & 25 & 45 & 57 & 71 & 80 & 87 \\
\hline Emiroglu dkk (2014) & 27 & 48 & 57 & 69 & 80 & 83 \\
\hline
\end{tabular}

\section{Metode Side Weir}

Perhitungan perencanaan dimensi side weir dengan lebar inlet floodway (sudetan) 16 meter dan lebar bersih 12 meter, untuk mencari nilai $\mathrm{Q}_{2}$ dan $\mathrm{Q}_{\mathrm{w}}$ yang tepat sehingga lebar floodway (sudetan) sesuai dengan percobaan.

Tabel 5. Tabel Perhitungan Debit di inlet dengan metode Side weir

\begin{tabular}{|c|c|c|c|}
\hline \multirow{2}{*}{$\operatorname{Tr}$} & $\begin{array}{c}\text { Debit } \\
\text { Ciliwung } \\
\text { Hulu }\end{array}$ & $\begin{array}{c}\text { Debit } \\
\text { Ciliwung } \\
\text { Hilir }\end{array}$ & $\begin{array}{c}\text { Debit Inlet } \\
\text { Sudetan }\end{array}$ \\
\cline { 2 - 4 } & $\mathrm{m}^{3} / \mathrm{det}$ & $\mathrm{m}^{3} /$ det & $\mathrm{m}^{3} /$ det \\
\hline 2 & 301 & 273 & 28 \\
\hline 5 & 400 & 350 & 50 \\
\hline 10 & 452 & 388 & 64 \\
\hline 25 & 509 & 440 & 69 \\
\hline 50 & 547 & 470 & 77 \\
\hline 100 & 572 & 490 & 82 \\
\hline
\end{tabular}

Dengan menggunakan persamaan (2) sampai dengan persamaan (7) diatas dan dengan mengasumsikan harga $\mathrm{W}$ dan $\mathrm{L}$ dan $\mathrm{E} 1$ $=\mathrm{E} 2=\mathrm{E} 3$, didapatkan $\mathrm{Q}_{\mathrm{w}}$ untuk kala ulang 2,
5, 10, 25, 50 dan 100 tahun adalah seperti pada tabel 4. Kesalahan relatif yang terjadi untuk debit floodway (sudetan) hasil perhitungan terhadap model fisik adalah berkisar antara $1,235 \%$ sampai $8,475 \%$.

\section{Metode Percabangan Anak Sungai}

Floodway (sudetan) dianggap sebagai anak sungai, sehingga diibaratkan adanya percabangan antara induk sungai Ciliwung dan anak sungai yaitu floodway (sudetan). Aliran yang terjadi dalam percabangan anak sungai ini harus bersifat subkritis. Jumlah debit pada percabangan anak sungai dan hulu sungai sama dengan debit sama dengan debit pada hilir sungai. Untuk menentukan ketinggian muka air pada Sungai Ciliwung dan floodway (sudetan) didapatkan dari lengkung debit. Percabangan anak sungai dengan sungai utama akan menghasilkan ketinggian muka air yang sama atau mendekati pada percabangan kedua sungai tersebut. Berdasarkan perhitungan 
tersebut didapatkan nilai $\mathrm{Q}$ dan ketinggian muka air dipercabangan sungai. Metode percabangan anak sungai menggunakan metode tahapan standar. Dengan perhitungan melalui metode percabangan anak sungai ini Tabel 6. Debit dan Elevasi Sungai Ciliwung dan Inlet Sudetan dengan Metode Percabangan Anak Sungai

\begin{tabular}{|c|c|c|c|}
\hline \multirow{2}{*}{$\operatorname{Tr}$} & $\begin{array}{c}\text { Debit } \\
\text { Ciliwung } \\
\text { Hulu }\end{array}$ & $\begin{array}{c}\text { Debit } \\
\text { Ciliwung } \\
\text { Hilir }\end{array}$ & $\begin{array}{c}\text { Debit } \\
\text { Inlet } \\
\text { Sudetan }\end{array}$ \\
\cline { 2 - 4 } & $\mathrm{m}^{3} / \mathrm{det}$ & $\mathrm{m}^{3} / \mathrm{det}$ & $\mathrm{m}^{3} / \mathrm{det}$ \\
\hline 2 & 301 & 274 & 27 \\
\hline 5 & 400 & 352 & 48 \\
\hline 10 & 452 & 393 & 59 \\
\hline 25 & 509 & 439 & 70 \\
\hline 50 & 547 & 469 & 78 \\
\hline 100 & 572 & 488 & 84 \\
\hline
\end{tabular}

Dari metode percabangan anak sungai didapatkan elevasi muka air Ciliwung Hulu, inlet floodway (sudetan) dan Ciliwung Hilir. Pada saat $\mathrm{Q}_{2}$ elevasi Sungai Ciliwung Hulu $+10,96$; elevasi Sungai Ciliwung Hilir $+10,63$ dan elevasi inlet floodway (sudetan) $+10,67$. Pada saat $\mathrm{Q}_{5}$ elevasi Ciliwung Hulu +11,78; elevasi Ciliwung Hilir $+11,33$ dan elevasi inlet floodway (sudetan) $+10,32$. Pada saat $\mathrm{Q}_{10}$ elevasi Sungai Ciliwung Hulu $+12,21$; elevasi Sungai Ciliwung Hilir $+11,66$ dan elevasi inlet floodway (sudetan) $+10,62$. Pada saat $Q_{25}$ elevasi Ciliwung Hulu +12,69; elevasi Ciliwung Hilir $+12,03$ dan elevasi inlet floodway (sudetan) $+12,01$. Pada saat $\mathrm{Q}_{50}$ elevasi Ciliwung Hulu $+13,02$; elevasi Ciliwung Hilir $+12,29$ dan elevasi inlet floodway (sudetan) $+12,26$. Pada saat Q100 elevasi Ciliwung Hulu $+13,22$; elevasi Ciliwung Hilir $+12,45$ dan elevasi inlet floodway (sudetan) $+12,41$.

\section{Metode Aliran Melalui Pulau}

Perhitungan aliran melalui pulau adalah dengan mencari perpotongan nilai ketinggian muka air pada suatu titik saat percabangan akibat melalui pulau.

Kasus ini terjadi pada Sungai Ciliwung hulu terhadap percabangan aliran Sungai Ciliwung hilir dan floodway (sudetan).

$\mathrm{Q}_{\text {hulu }}=\mathrm{Q}_{\text {hilir }}+\mathrm{Q}_{\text {sudetan }}$.

Metode aliran melalui pulau hampir sama dengan metode percabangan anak sungai, metode ini juga menggunakan metode tahapan standar (standar step method). Mula-mula dimisalkan debit $\mathrm{Q}_{1}$ dan $\mathrm{Q}_{2}$ untuk aliran yang didapatkan kesalahan relatif debit inlet hasil perhitungan terhadap model fisik berkisar antara $1,242 \%$ sampai $6,819 \%$.

Melalui perhitungan didapatkan hasil sebagai berikut:

terbagi tersebut sedemikian rupa sehingga jumlah debit ini sama dengan Q. Lalu menghitung profil-profil aliran dikedua saluran melalui setiap sisi ke titik A dimana aliran terpecah dua (gambar 3).

Tabel 7. Debit dan Elevasi Sungai Ciliwung dan Inlet Floodway (Sudetan) dengan Metode Aliran Melalui Pulau

\begin{tabular}{|r|c|c|c|}
\hline \multirow{2}{*}{$\operatorname{Tr}$} & $\begin{array}{c}\text { Debit } \\
\text { Ciliwung } \\
\text { Hilir }\end{array}$ & $\begin{array}{c}\text { Debit } \\
\text { Ciliwung } \\
\text { Hulu }\end{array}$ & $\begin{array}{c}\text { Debit } \\
\text { Inlet } \\
\text { Sudetan }\end{array}$ \\
\cline { 2 - 4 } & $\mathrm{m}^{3} /$ det & $\mathrm{m}^{3} /$ det & $\mathrm{m}^{3} /$ det \\
\hline 2 & 302,092 & 275,075 & 27,017 \\
\hline 5 & 401,213 & 353,071 & 48,142 \\
\hline 10 & 452,277 & 393,043 & 59,234 \\
\hline 25 & 509,763 & 439,406 & 70,356 \\
\hline 50 & 548,463 & 470,156 & 78,307 \\
\hline 100 & 573,433 & 488,894 & 84,539 \\
\hline
\end{tabular}

Berdasarkan perhitungan standart step method pada percabangan yang telah dilakukan maka dapat diketahui $\mathrm{Q}_{\text {hulu. }}$. Hasil perhitungan disajikan dalam tabel 6 . Dengan metode ini didapatkan kesalahan relatif debit di hulu Sungai Ciliwung $\left(\mathrm{Q}_{\text {hulu }}\right)$ hasil perhitungan terhadap $\mathrm{Q}_{\text {hulu }}$ model fisik berkisar antara $0,061 \%$ sampai $0,363 \%$.

\section{Simulasi HEC-RAS \\ Hasil Running HEC-RAS Debit Banjir Rancangan Kala Ulang 2 tahun}

Untuk debit banjir rancangan kala ulang 2 tahun $\left(\mathrm{Q}_{2}=301 \mathrm{~m}^{3} /\right.$ detik$)$ didapatkan debit yang masuk ke sudetan sebesar $31 \mathrm{~m}^{3} /$ detik dengan tinggi muka air $+10,62 \mathrm{~m}$. Elevasi dititik pertemuan yaitu untuk Sungai Ciliwung di hulu sudetan (STA 5+750) $+10,67 \mathrm{~m}$ sedangkan elevasi sungai ciliwung di hilir sudetan (STA 5+700) $+10,64$ m dengan debit $271 \mathrm{~m} 3 /$ detik. Kecepatan pada inlet 1,41 $\mathrm{m} /$ detik. Profil muka air dapat dilihat pada gambar 5.

\section{Hasil Running HEC-RAS Debit Banjir Rancangan Kala Ulang 5 tahun}

Untuk debit banjir rancangan kala ulang 5 tahun $\left(\mathrm{Q}_{5}=400 \mathrm{~m}^{3} /\right.$ detik$)$ didapatkan debit yang masuk ke sudetan sebesar $52 \mathrm{~m}^{3} /$ detik dengan tinggi muka air $+11,26 \mathrm{~m}$. Elevasi dititik pertemuan yaitu untuk Sungai Ciliwung 
di hulu sudetan (STA 5+750) +11,30m sedangkan elevasi sungai ciliwung di hilir sudetan (STA 5+700) +11,30m dengan debit $348 \mathrm{~m} 3 /$ detik. Kecepatan pada inlet 1,65 $\mathrm{m} /$ detik. Profil muka air dapat dilihat pada gambar 5.

\section{Hasil Running HEC-RAS Debit Banjir Rancangan Kala Ulang 10 tahun}

Untuk debit banjir rancangan kala ulang 10 tahun $\left(\mathrm{Q}_{10}=452 \mathrm{~m}^{3} /\right.$ detik $)$ hasil simulasi HECRAS didapatkan debit yang masuk ke sudetan sebesar $61 \mathrm{~m}^{3} /$ detik dengan tinggi muka air $+11,47 \mathrm{~m}$. Elevasi dititik pertemuan yaitu untuk Sungai Ciliwung di hulu sudetan (STA 5+750) $+11,64 \mathrm{~m}$ sedangkan elevasi sungai ciliwung di hilir sudetan (STA 5+700) $+11,64 \mathrm{~m}$ dengan debit $391 \mathrm{~m}^{3} /$ detik. Kecepatan yang tejadi pada inlet $1,64 \mathrm{~m} /$ detik. Profil muka air dapat dilihat pada gambar 5 .

\section{Hasil Running HEC-RAS Debit Banjir Rancangan Kala Ulang 25 tahun \\ Hasil simulasi HEC-RAS untuk debit} banjir rancangan kala ulang 25 tahun $\left(\mathrm{Q}_{25}=509\right.$ $\mathrm{m}^{3} /$ detik) didapatkan debit yang masuk ke sudetan sebesar $70 \mathrm{~m}^{3} /$ detik dengan tinggi muka air $+11,82 \mathrm{~m}$. Elevasi dititik pertemuan yaitu untuk Sungai Ciliwung di hulu sudetan (STA 5+750) 12,00m sedangkan elevasi sungai ciliwung di hilir sudetan (STA 5+700)
$+12,00 \mathrm{~m}$ dengan debit $439 \mathrm{~m}^{3} /$ detik. Kecepatan yang tejadi pada inlet $1,64 \mathrm{~m} /$ detik. Profil muka air dapat dilihat pada gambar 5.

\section{Hasil Running HEC-RAS Debit Banjir Rancangan Kala Ulang 50 tahun}

Untuk debit banjir rancangan kala ulang 50 tahun $\left(\mathrm{Q}_{50}=547 \mathrm{~m}^{3} /\right.$ detik $)$ didapat-kan debit yang masuk ke sudetan sebesar 79 $\mathrm{m}^{3} /$ detik dengan tinggi muka air $+12,16 \mathrm{~m}$. Elevasi dititik pertemuan yaitu untuk Sungai Ciliwung di hulu sudetan (STA 5+750) $+12,31 \mathrm{~m}$ sedangkan elevasi sungai ciliwung di hilir sudetan (STA 5+700) +12,31m dengan debit $468 \mathrm{~m}^{3} /$ detik. Kecepatan pada inlet 1,64 $\mathrm{m} /$ detik. Profil muka air dapat dilihat pada gambar 5.

\section{Hasil Running HEC-RAS Debit Banjir Rancangan Kala Ulang 100 tahun \\ Untuk debit banjir rancangan kala ulang 100 tahun $\left(\mathrm{Q}_{100}=572 \mathrm{~m}^{3} /\right.$ detik $)$ debit yang masuk ke sudetan sebesar $85 \mathrm{~m}^{3} /$ detik dengan tinggi muka air $+12,38 \mathrm{~m}$. Elevasi dititik pertemuan yaitu untuk Sungai Ciliwung di hulu sudetan (STA 5+750) +12,51m sedangkan elevasi sungai ciliwung di hilir sudetan (STA 5+700) +12,52m dengan debit $487 \mathrm{~m}^{3} /$ detik. Kecepatan yang tejadi pada inlet $1,65 \mathrm{~m} /$ detik. Profil muka air dapat dilihat pada gambar 5.}

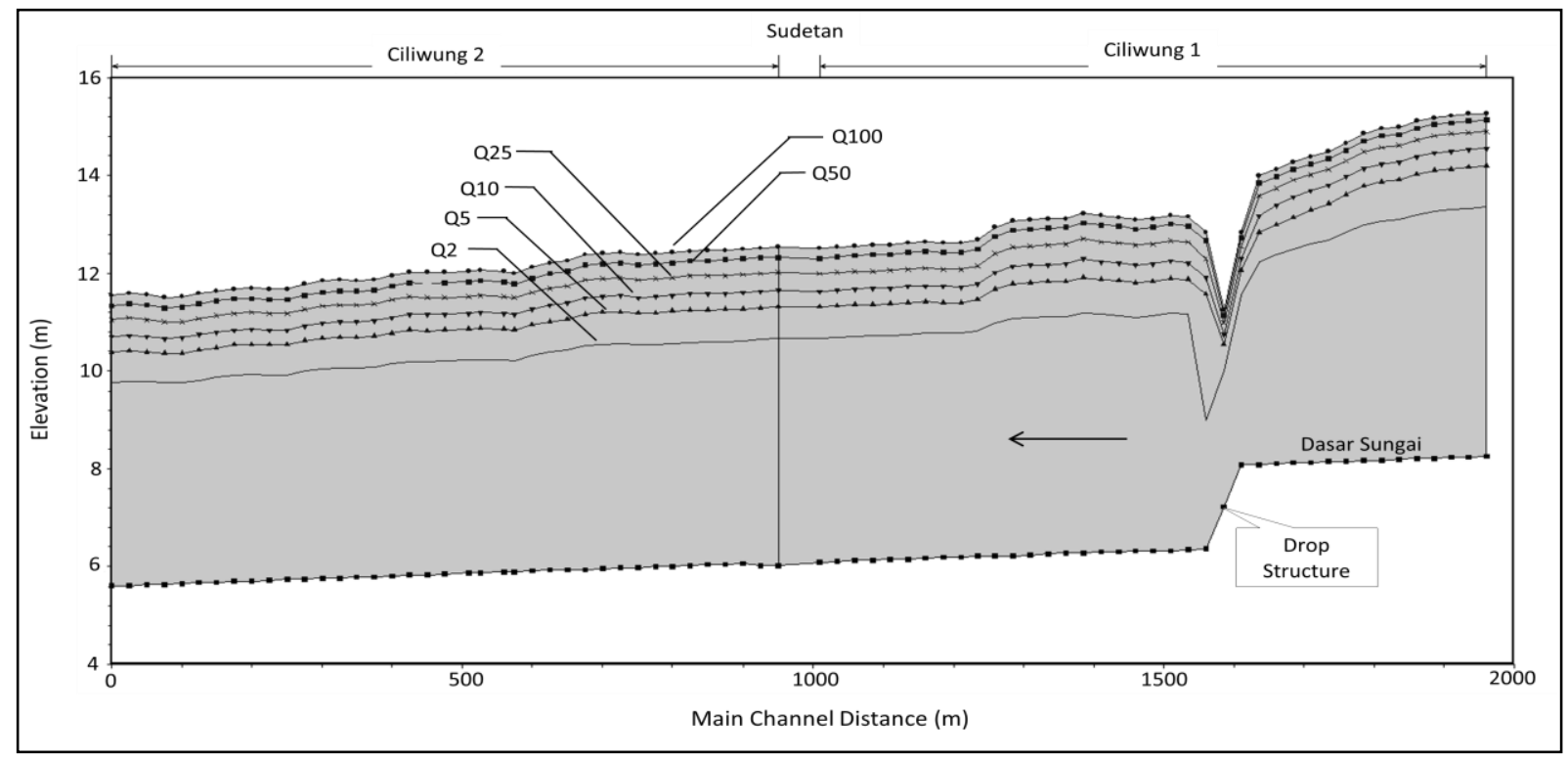

Gambar 5. Profil Muka Air Sungai Ciliwung kala ulang 2, 5, 10, 25, 50 dan 100 tahun 


\section{Evaluasi Hasil Hitungan Analitis \& Simulasi HEC-RAS terhadap Hasi Uji Model Fisik}

Dari hasil analisis yang dilakukan didapatkan kesalahan relatif debit inlet sudetan terhadap model fisik dengan menggunakan perhitungan analisis berkisar antara 0,233\% sampai $8,475 \%$ sedangkan HEC-RAS kesalahan relatif yang terjadi berkisar antara $0 \%$ sampai $6,897 \%$ seperti yang terlihat pada gambar 6.

Kesalahan relatif untuk kecepatan pada inlet floodway (sudetan) terhadap model fisik dengan menggunakan perhitungan analisis berkisar antara $0,998 \%$ sampai $13,102 \%$ sedangkan analisa dengan menggunakan alat bantu HEC-RAS kesalahan relatif yang terjadi berkisar antara $0,820 \%$ sampai $10,156 \%$ (gambar 7).

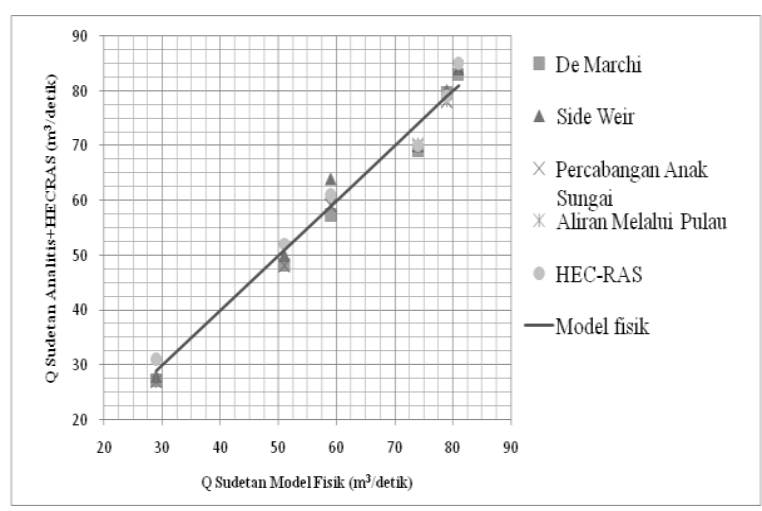

Gambar 6. Grafik Perbandingan Perhitungan Analitis dan HEC-RAS terhadap Model Fisik untuk Debit di Inlet Sudetan

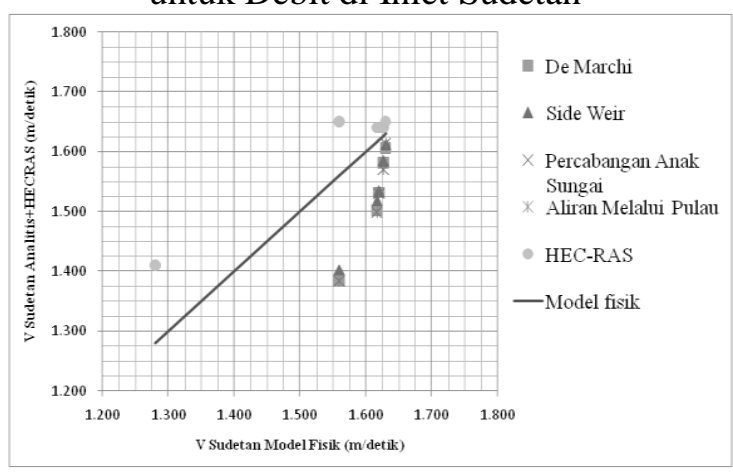

Gambar 7. Grafik Perbandingan Perhitungan Analitis dan HEC-RAS terhadap Model Fisik untuk Kecepatan di Inlet Sudetan

Sedangkan kesalahan relatif yang didapat untuk elevasi muka air pada inlet floodway (sudetan) berkisar antara 0,544\% sampai $2,581 \%$ sedangkan analisa dengan menggunakan alat bantu HEC-RAS kesalahan relatif yang terjadi berkisar antara $1,154 \%$ sampai 3,220\% (gambar 8).

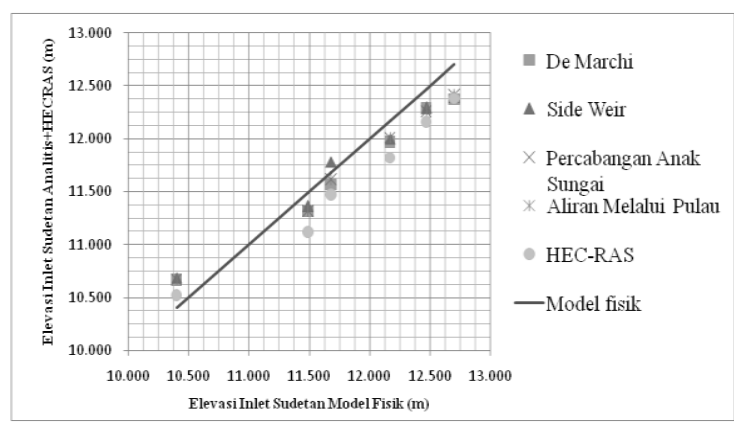

Gambar 8. Grafik Perbandingan Perhitungan Analitis dan HEC-RAS terhadap Model Fisik untuk Elevasi Muka Air di Inlet Sudetan

Dalam pembuatan model baik secara analitis, satu dimensi maupun pemodelan fisik selalu ada tingkat ketidakpastian dan pemahaman (level of uncertainty and understanding). Webber (1971) mengatakan bahwa tentang adanya ketidakpastian dalam membuat desain yang efisien dalam model hidrolik. Ketika model dibuat, ada berbagai kondisi spesifik di mana model akan paling akurat dan kondisi saat model mungkin memiliki lebih banyak ketidakpastian.

Untuk mengetahui kesesuaian model analitis dan HEC-RAS terhadap uji model fisik, digunakan Analisis regresi, Mean Absolut Error (MEA), Coeffisient Performance $(C p)$, dan Root Mean Square Error (RMSE).

\section{Analisis Regresi}

Analisis regresi adalah analisis yang membahas hubungan dua variable atau lebih. Dalam studi ini yaitu debit, kecepatan dan elevasi muka air hasil model fisik dengan debit, kecepatan dan elevasi muka air hasil hitungan analitis dan simulasi HECRAS.

Derajat hubungan tersebut umumnya dinyatakan secara kuantitatif sebagai koefisien korelasi.Nilai koefisien korelasi berkisar antara $-1,0<\mathrm{R}<1,0$.

Berdasarkan uji kolerasi dengan analisis regresi didapatkan hasil sebagaimana terdapat pada tabel 8 .

Untuk analisa regresi apabila nilai $\mathrm{R}^{2}$ mendekati 1, model semakin memiliki hubungan yang baik. Dari tabel 8 diketahui nilai $\mathrm{R}^{2}$ yang didapatkan berkisar antara 0,988 sampai 0,998 sehingga masuk kedalam kriteria 
hubungan langsung positif baik. Dari ke-5 metode yang digunakan secara umum simulasi HEC-RAS memiliki hasil yang paling baik.

Tabel 8. Hasil Analisa Regresi Pada Inlet dengan berbagai Metode Hitungan Analitis dan HECRAS

\begin{tabular}{|l|c|c|c|}
\hline \multirow{2}{*}{\multicolumn{1}{|c|}{ Metode }} & \multicolumn{3}{|c|}{${\text { Nilai } \mathrm{R}^{2}}$} \\
\cline { 2 - 4 } & Debit & Kecepatan & Elevasi \\
\hline De Marchi & 0,994 & 0,989 & 0,998 \\
\hline Side Weir & 0,990 & 0,990 & 0,998 \\
\hline $\begin{array}{l}\text { Percabangan } \\
\text { Anak Sungai }\end{array}$ & 0,993 & 0,988 & 0,998 \\
\hline $\begin{array}{l}\text { Aliran Melalui } \\
\text { Pulau }\end{array}$ & 0,993 & 0,988 & 0,998 \\
\hline HEC-RAS & 0,993 & 0,994 & 0,998 \\
\hline
\end{tabular}

Mean Absolute Error (MAE)

Mean Absolute Error (MAE) digunakan untuk mendeskripsikan kesalahan rata-rata dari kesalahan absolut dalam sebuah pemodelan.

$$
\mathrm{MAE}=n^{-1} \sum_{i=1}^{n}\left|e_{i}\right|
$$

$M A E=$ Nilai Mean Absolute Error (MAE)

$\mathrm{n} \quad=$ Jumlah periode waktu data

$e_{i} \quad=$ Kesalahan pada periode waktu i

Kriteria dari evaluasi ini adalah semakin kecil nilai MAE yang didapatkan, maka semakin baik hubungan yang dihasilkan dan sebaliknya.

Perhitungan nilai Mean Absolute Error (MAE) secara keseluruhan dapat dilihat di lampiran sedangkan rekapitulasinya disajikan pada tabel 9 berikut ini:

Tabel 9. Nilai Mean Absolute Error (MAE) untuk Perhitungan Analitis dan Simulasi HEC-RAS tehadap Hasil Model Fisik

\begin{tabular}{|l|c|c|c|}
\hline \multirow{2}{*}{\multicolumn{1}{|c|}{ Metode }} & \multicolumn{3}{c|}{ Nilai MAE } \\
\cline { 2 - 4 } & Debit & Kecepatan & Elevasi \\
\hline De Marchi & 2,295 & 0,101 & 0,212 \\
\hline Side Weir & 2,500 & 0,091 & 0,194 \\
\hline $\begin{array}{l}\text { Percabangan } \\
\text { Anak Sungai }\end{array}$ & 2,204 & 0,104 & 0,195 \\
\hline $\begin{array}{l}\text { Aliran Melalui } \\
\text { Pulau }\end{array}$ & 2,159 & 0,104 & 0,195 \\
\hline HEC-RAS & 2,295 & 0,049 & 0,280 \\
\hline
\end{tabular}

Dari hasil perhitungan evaluasi model dengan menggunakan metode MAE (tabel 9) dapat disimpulkan bahwa untuk perhitungan debit pada inlet sudetan dengan metode aliran melalui pulau memiliki hasil yang paling baik, untuk kecepatan dan elevasi muka air simulasi HEC-RAS memiliki hasil yang paling baik.

\section{Coefficient Performance (Cp)}

Coefficient Performance ( $\mathrm{Cp}$ ) berfung-si mengevaluasi perbedaan prosedur statistik prediksi hidrologi aliran air yaitu besaran debit uji model fisik dengan hasil perhitungan analitis dan simulasi HEC-RAS. Kriteria untuk masing-masing nilai $C p$ dapat dilihat pada tabel 9. berikut.

Hasil perhitungan didapatkan nilai $\mathrm{Cp}$ untuk debit pada inlet sudetan berkisar antara 0,0169 sampai 0,0244 , berdasarkan tabel 10 maka untuk setiap metode perhi-tungan dan analisa HEC-RAS masuk kedalam kriteria sempurna. Untuk kecepat-an pada inlet sudetan didapatkan nilai $\mathrm{Cp}$ berkisar antara 0,315 sampai 0,439, masuk kedalam kriteria bagus. Untuk elevasi muka air pada inlet sudetan didapatkan nilai $\mathrm{Cp}$ berkisar antara 0,119 sampai 0,189 , sehingga masuk kedalam kriteria sempurna.

Tabel 10. Kriteria Nilai Coefficient Performance $(\mathrm{Cp})$

\begin{tabular}{|c|c|c|}
\hline No. & $C p$ & Keterangan \\
\hline 1. & $0.00-0.30$ & Sempurna \\
\hline 2. & $0.30-0.50$ & Bagus \\
\hline 3. & $0.50-0.70$ & Rata-rata \\
\hline 4. & $0.70-1.00$ & Jelek \\
\hline 5. & $>1.00$ & $\begin{array}{c}\text { Prediksi lebih jelek } \\
\text { daripada pengamatan }\end{array}$ \\
\hline
\end{tabular}

Sumber : Hambali, 2008 dalam Sulfandi 2015

\section{Root Mean Square Error (RMSE)}

Salah satu indikator statistik yang umum digunakan untuk mengukur seberapa dekat hasil simulasi dengan hasil pengukuran adalah dengan menggunakan Root Mean Square Error (RMSE). RMSE merupakan parameter yang digunakan untuk mengevaluasi nilai hasil dari pengamatan/ pengukuran terhadap nilai sebenarnya atau nilai yang dianggap benar. Nilai RMSE menyatakan seberapa tepat perbandingan antara debit hasil simulasi atau perhitungan dengan model fisik. Rumus yang digunakan untuk menghitung nilai RMSE adalah sebagai berikut. 
$R M S E=\sqrt{\frac{1}{N}\left[\sum_{i=1}^{N}\left[\hat{X}_{i}-X_{i}\right]^{2}\right]}$

dengan:

$\hat{X}_{i}=$ Hasil perhitungan/pemodelan

$X_{i} \quad=$ Data model fisik

$N \quad=$ Jumlah data

Semakin besar nilai RMSE, hasil estimasi model yang dihasilkan semakin tidak tepat bila dibandingkan dengan pengamatan dan sebaliknya bila nilai RMSE mendekati nol maka estimasi model semakin baik.

Dari hasil perhitungan evaluasi model dengan menggunakan metode Root Mean Square Error (RMSE) didapatkan hasil sebagai berikut:

Tabel 11. Nilai RMSE untuk Perhitungan Analitis dan Simulasi HEC-RAS tehadap Hasil Model Fisik

\begin{tabular}{|l|c|c|c|}
\hline \multirow{2}{*}{ Metode } & \multicolumn{3}{|c|}{ Nilai RMSE } \\
\cline { 2 - 4 } & Debit & Kecepatan & Elevasi \\
\hline De Marchi & 2,657 & 0,115 & 0,223 \\
\hline Side Weir & 2,972 & 0,104 & 0,209 \\
\hline $\begin{array}{l}\text { Percabangan } \\
\text { Anak Sungai }\end{array}$ & 2,570 & 0,119 & 0,209 \\
\hline $\begin{array}{l}\text { Aliran Melalui } \\
\text { Pulau }\end{array}$ & 2,531 & 0,119 & 0,209 \\
\hline HEC-RAS & 2,531 & 0,066 & 0,209 \\
\hline
\end{tabular}

Dari hasil evaluasi metode perhitungan diatas (metode De Marchi, side weir, percabangan anak sungai, aliran melalui pulau dan simulasi HEC-RAS) dengan beberapa uji statistik (Analisis regresi, Mean Absolut Error, Coeffisient Performance, dan Root Mean Square Error) di atas diketahui bahwa simulasi HEC-RAS memiliki hasil yang paling baik bila dibanding metode lain karena hasil simulasi HEC-RAS memiliki hasil yang paling mendekati dengan uji model fisik baik debit, kecepatan maupun elevasi muka air.

Dan secara hitungan analitis maupun simulasi HEC-RAS debit $60 \mathrm{~m}^{3} /$ detik dapat tercapai sesuai kriteria perencanaan. Debit 60 m3/detik terjadi pada saat elevasi muka air Sungai Ciliwung berada di atas $+12,342$.

\section{KESIMPULAN}

Berdasarkan hasil analisa dan pembahasan yang telah dilakukan, maka dapat diambil kesimpulan sebagai berikut:

1. Dari hasil uji statistik yang dilakukan terhadap parameter debit, kecepatan dan elevasi muka air di inlet sudetan diketahui bahwa parameter debit memiliki hasil yang paling mendekati model fisik dengan kala ulang 50 tahun.

2. Secara umum metode dengan menggunakan simulasi HEC-RAS memiliki hasil yang paling mendekati dengan uji model fisik bila dibanding metode lain karena memiliki kesalahan relatif rata-rata paling kecil dan secara uji statistik untuk debit, kecepatan dan elevasi muka air masuk kedalam kriteria yang paling baik.

\section{DAFTAR PUSTAKA}

Badan Penanggulangan Bencana Daerah Provinsi DKI Jakarta. (2016). Rencana Penanggulangan Bencana Provinsi DKI Jakarta. Jakarta: BPPD DKI Jakarta.

Balai Besar Wilayah Sungai Ciliwung Cisadane. (2015). Laporan Pemodelan Fisik Hidrolika-2 Pembangunan Sudetan Sungai Ciliwung Ke Kanal Banjir Timur. Jakarta: BBWS Ciliwung-Cisadane.

Bagheri, S., A.R. Kabiri-Samani, M. Heidarpour. (2004). Discharge coefficient of rectangular sharp-crested side weirs, Part I: Traditional weir equation. Elsevier Flow Measurement and Instrumentation. 35 (2014) 109-115.

Borghei, M., M.R. Jalili, M. Ghodsian. (1999). Discharge coefficient for sharp-crested side weir in subcritical flow. ASCE Journal of Hydraulic Engineering. 125(10) : 1051-6.

Cheong, H. F. (1991). Discharge coefficient of lateral diversion from trapezoidal channel. ASCE Journal of Irrigation and Drainage Engineering. 117(4): 321-33.

Chow, V., (1997). Hidrolika Saluran Terbuka (Open Channel Hydraulics). Cetakan Keempat. Jakarta: Erlangga.

Departemen Pekerjaan Umum. (1986). Standar Perencanaan Irigasi, Kriteria Perencanaan Bagian Bangunan, KP-04. Jakarta.

Emiroglu, M.E., Agaccioglu, H., Kaya, N., (2011). Discharging capacity of rectangular side weir in straight open channels, Elsevier Flow Measurement and Instrumentation. 22 (2011) 319-330.

Ghodsian, M. Supercritical flow over rectangular side weir. (2003). Canadian Journal of Civil Engineering. 30(3): 596600.

Hager, W. H. Lateral outflow over side weirs. (1987). ASCE Journal of Hydraulic Engineering. 113(4):491-504. 
Jalili MR, S.M. Borghei. (1996). Discussion of 'Discharge coefficient of rectangular side weir. ASCE Journal of Irrigation and Drainage Engineering. 122(2): 132.

Ranga Raju, K.G. (1986). Aliran Melalui saluran Terbuka. Terjemahan Oleh Y. P. Pangaribuan. Jakarta: Erlangga.
Sulfandi. (2015). Studi Pengaruh Perubahan Tataguna Lahan Di DAS Mamasa terhadap Usia Guna Waduk PLTA Bakaru. Tesis. Malang: Universitas Brawijaya.

Webber, N. B., (1971). Fluid Mechanics for Civil Engineers. London: Chapman and Hall. 